\title{
Acts of State, State Immunity, and Judicial Review IN THE United StaTes
}

\author{
Zia Akthar* \\ Sussex University
}

\begin{abstract}
The doctrine of the Act of State and State Immunity has its foundation in common law frameworks. It is settled law that there is no cause of action that will make a foreign state liable in the domestic court of another country. In the United States there has been acceptance that certain cases involve "political questions" that are non-justiciable, as they are not a "case or controversy" as required by Article III of the U.S. Constitution. The courts have only intervened either where the federal statutes have applied extraterritorially, such as under the Civil Rights Act 1964 where a U.S. citizen is employed abroad by a company registered in the United States, or under the Alien Tort Claims Act (ATCA) 1789, which protects foreign parties who are designated sufficiently "alien" for the sole purpose of invoking jurisdiction after a civil wrong has been committed against them. There needs to be an evaluation of the U.S. Supreme Court precedents that have asserted judicial oversight in respect of wrongs committed extra-territorially, and their present rationale for retaining the doctrine. This paper also discusses the scope of the Federal State Immunity Act (FSIA) and the Justice Against Sponsors of Terrorism Act (JASTA) that narrow the concept of state immunity when dealing with terrorism by another state or its agents. A comparative analysis with the state immunity doctrine in Canada and the framework for litigation under the merits-based approach by the courts is provided. The common law courts have developed the doctrine of the Act of State and it has become a principle of customary international law. The argument of this paper is that there needs to be a greater focus on the civil injuries that are caused in other jurisdictions that should allow the claimants to litigate in the forum court and for judicial review to be available.
\end{abstract}

\section{KEYWORDS}

Sovereign immunity; Article III; judicial restraint; ATCA; territoriality principle; JASTA; merits-based approach.

\section{CONTENTS}

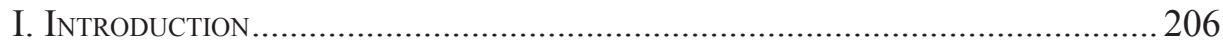

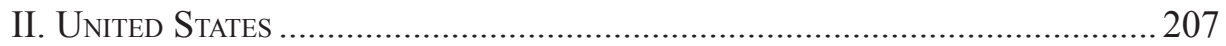

A. Non-Justiciability and the Political Question Doctrine ....................... 207

B. Challenging the Executive Powers of State ………………………....... 211

C. Constitutional Review of State Immunity...........................................2214

* LLB (Lon), LLM (Lon), Gray's Inn, Doctoral Candidate, Sussex University. The author acknowledges with thanks the helpful comments of the anonymous reviewers of this article and the considerable editorial assistance of members of the editorial team of the British Journal of American Legal Studies 
D. Extraterritorial Jurisdiction and Tort Liability ............................216

E. Impact of JASTA on State Immunity ..........................................223

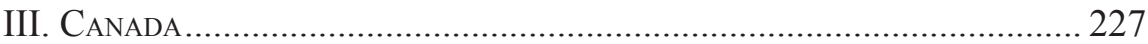

A. Sovereign Immunity in Law ....................................................227

B. Merits-Based Approach .............................................................229

C. Liability of Foreign Countries for Terrorist Conduct ..................230

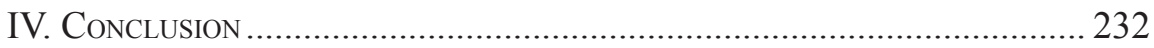

\section{INTRODUCTION}

International relations have been governed by the concept of sovereign immunity of states which prevents litigation against them in foreign courts. This concept is based on the doctrine of act of state which grants immunity from wrongdoing to the state for any alleged breach of law. When pleaded in court, judges may deny the private party's cause of action against the invoking state. The existence of sovereign immunity places an absolute bar on judicial review in the domestic courts and, in the United States, is regarded as part of the doctrine of separation of powers. There are statutory exceptions to the law of sovereign immunity when the Supreme Court has review powers over external acts that give rise to a cause of action in U.S. courts for breaches of duty in another country.

The protection for the state under both state immunity and "act of state" doctrines protects individual states and their institutions from scrutiny where they act unlawfully either together or in common with other states and impinges on the ability of private individuals to secure redress. In the common law traditions, the level of restriction on the traditional absolute theory of sovereign immunity has now become the subject of national legislation. The United States was the first to enact a law in the form of the Foreign Sovereign Immunities Act of 1976, followed by State Immunity Act 1978 in the United Kingdom, and in Canada the promulgation of the Foreign State Immunities Act 1985.

The concept of state immunity is based on the common law process of legal precedents developed by the courts. In England, the doctrine of "act of state" is based on judicial restraint rather than constitutional competence. The case for application of the doctrine is subject to close scrutiny and it has been qualified by decisions in the courts that have recognized that non-justiciability is not an absolute principle. ${ }^{1}$ The act of state doctrine's origin in the United States was when cases were initiated against officials of foreign governments and the personal immunity of foreign sovereigns was established. It placed limitations on judicial review where the courts respected the right of the executive to deny jurisdiction.

For a general description of the history and development of the act of state doctrine in the United Kingdom, see Michael Singer, The Act of State Doctrine of the United Kingdom: An Analysis with Comparisons to United States Practice, 75 Am. J. InT'L L. 283, 284-96 (1981). 
One constitutional safeguard is that certain cases have been designated as involving "political questions." Such cases are non-justiciable, as they are not a "case or controversy" as required by Article III of the U.S. Constitution which only allows judicial intervention in such circumstances. ${ }^{2}$ The issue the courts face is the extent to which this rule has been circumvented by the doctrine of separation of powers which, unlike in other common law systems, is a central tenet of the U.S. constitution.

Certain extra-territorial breaches involving either U.S. citizens or those foreign citizens affected by an act of a federal agency confer a power of review on federal courts overriding any state immunity. This exists in two instances: the Civil Rights Act 1964, Title VII and the Alien Torts Act 1791, originally enacted as section 9 of the Judiciary Act of 1789 , that grants the district courts original jurisdiction over "any civil action by an alien for a tort only, committed in violation of the law of nations or a treaty of the United States". ${ }^{3}$ It provides redress for non-U.S. citizens who may bring a civil suit in the federal courts. The preservation of sovereign immunity until now has kept the separation of powers doctrine intact and not only prevented the United States government holding a foreign state liable in its courts but neither has there been a reciprocal power for foreign courts to try U.S. citizens for grave breaches of international law. The cases need analysis to determine the strength of the doctrine that has been a central tenet of public international law. This paper presents a comparative approach by also evaluating the Canadian courts' merits-based approach to set out the need for increased judicial activism in this area of law.

\section{UNITED STATES}

\section{A. Non-Justiciability and the Political Question Doctrine}

In the United States, the act of state doctrine excludes jurisdiction in cases that involve "political questions". This is because the separation of powers doctrine vests the executive with its own domain of authority. A right of challenge may exist where a private right of a citizen has been infringed, when the courts will, in principle, exercise their powers of judicial review. ${ }^{4}$ However, when the issue relates

2 U.S. Constitution Article III, Section 2 states:

The judicial power shall extend to all cases, in law and equity, arising under this Constitution, the laws of the United States, and treaties made, or which shall be made, under their authority;--to all cases affecting ambassadors, other public ministers and consuls;--to all cases of admiralty and maritime jurisdiction;--to controversies to which the United States shall be a party;-to controversies between two or more states;--between a state and citizens of another state;--between citizens of different states;--between citizens of the same state claiming lands under grants of different states, and between a state, or the citizens thereof, and foreign states, citizens or subjects.

3 Judiciary Act of 1789, ch. 20, $\S 9$ (b), 1 Stat. 73, 77 (currently, with some changes, 28 U.S.C. $\$ 1350(1982)$ ).

4 In the United States, the constitution has been interpreted to provide a balance of powers that can enquire into the legality of the executive's actions. These can be challenged and 
to acts of a foreign state acting intra vires, then those actions are not reviewable by federal courts under the Article III of the U.S. Constitution. ${ }^{5}$

The context in which the doctrine of act of state has developed and is invoked needs to be appreciated when there is a challenge to an act of state in the domestic courts. This can be by contrasting the concept that prevails at common law from which the act of state doctrine originates. In English law, the act of state doctrine can be accurately described as being a product of the common law and not international law and it has similar origins to the U.S. doctrine. ${ }^{6}$ There is a denial of private rights in its application and it is based on notions that parallel other methods of jurisdictional control and regulation in cases involving foreign states.

Lord Wilberforce's principle of "non-justiciability" was elucidated in Buttes Gas \& Oil Co. v. Hammer (No.3) [1982] A.C. 888 as follows:

But, the ultimate question what issues are capable, and what are incapable, of judicial determination must be answered in closely similar terms in whatever country they arise, depending, as they must, upon an appreciation of the nature and limits of the judicial function. This has clearly received the consideration of the United States courts. When the judicial approach to an identical problem between the same parties has been spelt out with such articulation in a country, one not only so closely akin to ours in legal approach, the fabric of whose legal doctrine in this area is so closely interwoven with ours, but that to which all the parties before U.S. belong, spelt out moreover in convincing language and reasoning, we should be unwise not to take the benefit of it. $^{7}$

The principle of non-justiciability has been extended to the standard of proof to be satisfied by a party which asserts that justice has not been done in a foreign jurisdiction. ${ }^{8}$ His Lordship also considered whether it was open to allege that as

a body required to submit to a writ of mandamus. The rule was stated by the Supreme Court in Marbury v Madison, 5 U.S. (1 Cranch) 137 (1803), where it stated that the discretionary executive actions of the government are not usually reviewable, "but where a specific duty is assigned by law, and individual rights depend upon the performance of that duty, it seems equally clear that the individual who considers himself injured has a right to resort to the laws of his country for a remedy". Id. at 166.

5 In Underhill v. Hernandez, 168 U.S. 250, 252 (1897), Fuller, C.J. established the principle of the act of state in the following terms:

Every sovereign state is bound to respect the independence of every other sovereign state, and the courts of one country will not sit in judgment on the acts of the government of another done within its own territory. Redress of grievances by reason of such acts must be obtained through the means open to be availed of by sovereign powers as between themselves.

$6 \quad$ It is worth noting that the Supreme Court decision in Oetjen v. Central Leather Co. 246 U.S. 297 (1918), which affirmed the decision in Underhill, 168 U.S. 250, was referred to in the judgments in Luther v. Sagor \& Co [1921] 3 KB 532 and Princess Paley Olga v. Weisz [1929] 1 K.B. 718, Scrutton, L.J. in the latter stating that English law on the point was the same as American law (Princess Paley, at 724-25; 728-29).

7 Buttes Gas \& Oil Co. v. Hammer (No.3) [1982] A.C. 888, 937.

8 In Kuwait Airways Corp. v. Iraqi Airways Co. (Nos 4 \& 5) [2002] UKHL 19, the House of Lords identified three separate issues arising when English courts are called upon to adjudicate what might otherwise be a wrong and are offered foreign legislative or executive 
a result, for example, of endemic corruption, the principle of justice cannot be achieved in the foreign legal system. The principle of state immunity (or sovereign immunity) is for the legislative or executive acts of foreign states. This aspect of the act of state doctrine has been refined by common law and statute in the United Kingdom and is increasingly determined by its limitations, rather than by providing the state with a discretion as to when an exception will be allowed.

Whereas Buttes involved issues concerning several foreign states, the political question doctrine developed as a reaction to both internal and external circumstances. This is the reasoning that underlies the wider application of the political question doctrine in relation to the concept of non-justiciability. It is the basis for the claim that the political question doctrine originates from English precedent and is premised upon concerns different from the contemporary Buttes doctrine. ${ }^{9}$

Lord Hope stated further that this did not provide an absolute rule and it was subject to an exception based on public policy. This is effective "if the foreign legislation constitutes so grave an infringement of human rights that the courts of this country ought to refuse to recognise the legislation as a law at all". ${ }^{10}$ The public policy exception was to be very narrowly construed and that the only exception which the courts accepted was based on human rights. ${ }^{11}$

The concept of the political question doctrine arose in the United States at the turn of the 19th century when the U.S. Supreme Court held that policy considerations in foreign relations made certain issues inappropriate for judicial hearing. ${ }^{12}$ The implication was that disputes of a political nature, or those within the discretion of the executive, were non-justiciable. ${ }^{13}$ However, the rulings did not declare a recognized principle until the decision in the seminal case of Baker v. Carr, where the appellants had qualified to vote for members of the General Assembly of Tennessee representing the counties in which they resided. The group claimants served proceedings in a federal district court under 42 U.S. C. $\S \S 1983$ and 1988 , on behalf of themselves and others, to redress the alleged deprivation of their federal constitutional rights by the State's failure to enact redistricting legislation equalizing representation in the Tennessee General Assembly. ${ }^{14}$

acts by way of defense. The first was the accepted rule that a foreign sovereign is to be accorded absolute authority to act as a sovereign within its own territory; the second is whether the sovereign was acting within its own territorial jurisdiction or not and, finally, there is a certain class of sovereign act which requires judicial deference, called nonjusticiability, on the part of the English domestic court. Lord Hope ruled: "There is no doubt as to the general effect of the rule which is known as the act of state rule. It applies to the legislative or other governmental acts of a recognised foreign state or government within the limits of its own territory. The English courts will not adjudicate upon, or call into question, any such acts. They may be pleaded and relied upon by way of defence in this jurisdiction without being subjected to that kind of judicial scrutiny." Id. at $₫ 135$.

9 In Coleman v. Miller, 307 U.S. 433, 460 (1939), Frankfurter, J. held that this principle extended as far back as the $15^{\text {th }}$ century, citing Duke of York's Claim to the Crown (1460) 5 Rot. Parl. 375. In Coleman, the U.S. Supreme Court recognized that the doctrine was both part of the separation of powers as well as a limitation on justiciability. Coleman, at 454-55 (Hughes, C.J.).

10 Kuwait Airways Corp. v. Iraqi Airways Co. (No’s 4 \& 5) [2002] UKHL 19, ๆ137.

11 Id.

12 Ware v. Hylton, 3 U.S. (3 Dall.) 199 (1796).

13 Marbury v. Madison, 5 U.S. 137, 170 (1803) (Marshall, C.J.).

14 Baker v. Carr, 369 U.S. 186 (1962). 
The issue was that a 1901 statute of Tennessee arbitrarily divided the seats in the legislature among the State's 95 counties, and Tennessee had failed to reapportion them afterwards despite the substantial increase and redistribution of the State's population. This meant that the claimants suffered from a "debasement of their votes," and were, therefore, denied the equal protection of the laws guaranteed to them under the Fourteenth Amendment.

The application for a declaratory injunction restraining certain state officers from organizing any further elections was denied by the district court on the basis that it lacked jurisdiction of the subject matter and that no relief could be granted. The case reached the U.S. Supreme Court where the majority considered the case was justiciable. ${ }^{15}$

Justice Brennan, in a 6-2 majority verdict, delivered the opinion for the Court holding that by virtue of debasement of their votes, the appellants' allegations of a denial of equal protection presented a justiciable constitutional cause of action upon which they were entitled to a trial and a decision. The right asserted was within the reach of judicial protection under the Fourteenth Amendment. ${ }^{16}$ This established the precedent for the "political question doctrine" and it remains the leading case. However, unlike the Buttes case, the decision in Baker did not involve foreign states or external considerations but concerned the alleged failure of the State legislature of Tennessee to abide by its constitutional provisions on the designation of legislative districts.

The dissenting justices, Frankfurter and Harlan, JJ. ${ }^{17}$ held that the case was "masquerading" as a legal claim and was not justiciable "by virtue of the very fact that a federal court is not a forum for political debate". ${ }^{18}$ Frankfurter, J. stated that the courts, "must remain completely detached from "political entanglements" and abstain "from injecting [themselves] into the clash of political forces in political settlements". ${ }^{19}$ The implication was that the role of the courts in hearing disputes would often be compromised in a very wide interpretation of judicial restraint which led to the judicial consensus on the existence of the political question doctrine.

The ruling of the Court identified six factors, the presence of one or more of which would render a case non-justiciable. This established the principle that "it is [an] error to suppose that every case or controversy which touches foreign relations lies beyond judicial cognizance". ${ }^{20}$ In the following circumstances, cases would be held non-justiciable when there was a

textually demonstrable constitutional commitment of the issue to a coordinate political department; or a lack of judicially discoverable and manageable standards for resolving it; or the impossibility of deciding without an initial policy determination of a kind clearly for non-judicial discretion; or the impossibility of a court's undertaking independent resolution without expressing lack of the respect due [to] coordinate branches of government;

15 Id. at 226 (Brennan, J.), 241 (Douglas, J., concurring), 251 (Clark, J., concurring), and 265 (Stewart, J., concurring).

Id. at 237.

Id. at 297 (Frankfurter, J.).

Id. at 330 (Harlan, J.).

Id. at 267 (Frankfurter, J.).

20 Baker v. Carr, 369 U.S. 186, 211 (1962) (Brennan, J.). 
or an unusual need for unquestioning adherence to a political decision already made; or the potentiality of embarrassment from multifarious pronouncements by various departments on one question. ${ }^{21}$

These factors are broad in scope and could cover a range of cases and this has caused much criticism of the doctrine. ${ }^{22}$ There have been some scholars who have suggested that the doctrine is in perpetual decline. ${ }^{23}$ However, other commentators have suggested that the political question doctrine should be retained. ${ }^{24}$ The political question doctrine is a firmly entrenched rule of American constitutional law and it separates the role of the branches of government but, in giving cognizance to the view that some cases can be heard if there are principles at stake, the courts have set out the basis of a review of acts of state.

\section{B. Challenging the Executive Powers of State}

There have been many decisions in the U.S. courts on the "political question" doctrine both pre- and post-Baker v. Carr that have involved considerations internal to the United States and many of the judgments have no impact in relation to transactions involving foreign states. ${ }^{25}$ There have also been occasions when they have arisen where this has often been in respect of attempts to bring about changes in the foreign policy of the federal government. ${ }^{26}$ Whilst at times application of the

Id. at 217 .

22 See, e.g, Michael E. Tigar, Judicial Power, The "Political Question Doctrine," and Foreign Relations, 17 UCLA L. Rev. 1135 (1970); Louis Henkin, Is There a "Political Question” Doctrine?, 85 Yale L. J. 597 (1976); Martin H. Redish, Judicial Review and the "Political Question", 79 Northwestern U. L. Rev. 1031 (1985); Jonathan I. Charney, Judicial Deference in Foreign Relations, 83 Am. J. InT'L L., 805 (1989). Criticism has also been levelled at the doctrine in the Supreme Court of Canada. In Operation Dismantle v. The Queen, [1985] 1 SCR 441, 469-70 ('Operation Dismantle'), Wilson, J. said that Justice Brennan's statement in Baker v. Carr was not helpful in determining when the six factors come into play. Her Honour said that past decisions of the U.S. Supreme Court were highly embarrassing to those in the executive or legislature, for e.g, Marbury v Madison, 5 U.S. 137, 170 (1803) and U.S. v. Nixon, 418 U.S. 683 (1974).

23 See, e.g, R. Brook Jackson, The Political Questions Doctrine: Where Does It Stand after Powell v. McCormack, O’Brien v. Brown, and Gilligan v. Morgan, 44 U. of CoL. L. REv. 477 (1973); Rachel E. Barkow, More Supreme than Court? The Fall of the Political Question Doctrine and the Rise of Judicial Supremacy, 102 Colum. L. ReV. 237 (2002).

24 See, e.g, Alexander M. Bickel, The Least Dangerous Branch: The Supreme Court at the Bar of Politics 183-98 (1962); J. Peter Mulhern, In Defense of the Political Question Doctrine, 137 U. Penn. L. Rev. 97 (1988); Jesse H. Choper, The Political Question Doctrine: Suggested Criteria, 54 Duke L. J. 1457 (2005).

25 See, e.g, Powell v. McCormack, 395 U.S. 486 (1969); Gilligan v Morgan, 413 U.S. 1 (1973); Consumers Union of U.S., Inc v. Periodical Correspondents' Ass'n, 515 F.2d 1341 (D.C. Cir. 1975); Metzenbaum v. Fed. Energy Reg. Comm., 675 F.2d 1282 (D.C. Cir. 1982); McIntyre v. O’Neill, 603 F.Supp. 1053 (D.C. Cir. 1985); Davis v. Bandemer, 478 U.S. 109 (1986).

26 See, e.g, Atlee v. Laird, 347 F.Supp 689 (E.D. Penn. 1972); Holtzman v. Schlesinger, 414 U.S. 1321 (1973); Goldwater v. Carter, 444 U.S. 996 (1979); Ramirez de Arellano 
doctrine may arise in relation to issues concerning foreign states, it is clear from these six factors identified by Justice Brennan in Baker that support for judicial restraint in public international law in private litigation was not within the scope of the political question doctrine. ${ }^{27}$

The interplay between the application of the political question doctrine and public international law is provided by the same concept on which the House of Lords created its doctrine of non-justiciability. The action in the United Kingdom courts which culminated in Buttes, also had its American counterpart when the plaintiff Occidental launched two lawsuits in the United States at the same time as commencing litigation in England. This litigation in the United States alleged conspiracy and unlawful interference in respect of the decree made by the Ruler of Sharjah. ${ }^{28}$ However, the Californian district court granted a motion to dismiss the first claim by reference to the act of state doctrine and it declined to make inquiries "into the authenticity and motivation of the acts of foreign sovereigns" because those would be "the very sources of diplomatic friction and complication that the act of state doctrine aims to avert". ${ }^{29}$ In Buttes, Lord Wilberforce described these lawsuits as "closely similar" to allegations that were before him in the House of Lords in England." ${ }^{30}$ His Lordship had ruled that the act of state doctrine was inapplicable. ${ }^{31}$

There was subsequent litigation in the United States brought three years later based on similar allegations, but the claims made related to the tortious conversion of cargoes of oil extracted and shipped from the area of disputed sovereignty and imported into the United States. Summary judgment against Occidental was granted. ${ }^{32}$ This was affirmed by the Fifth Circuit U.S. Court of Appeals on the basis that the case would involve "resolution of a territorial dispute between sovereigns", a political question upon which the Court was "powerless" to adjudicate. ${ }^{33}$ In its judgment, all six Baker factors that excluded its jurisdiction were relevant. ${ }^{34}$ This was because firstly, the resolution of the ownership of disputed foreign lands is constitutionally entrusted to the executive; ${ }^{35}$ secondly, judicial or manageable standards are lacking in the determination of sovereignty; ${ }^{36}$ thirdly, in the absence of an executive decision on the sovereignty of the area, judicial determination

v. Weinberger, 745 F.2d 1500 (D.C. Cir. 1984); Lowry v. Reagan, 676 F.Supp 333 (D.C. 1987); Made in the USA Found'n v. U.S., 242 F 3d 1300 (11th Cir. 2001).

27 Occidental Petroleum Corp. v. Buttes Gas \& Oil Co, 331 F.Supp 92 (C.D. Cal. 1971); aff'd Occidental Petroleum Corp. v. Buttes Gas \& Oil Co, 461 F.2d 1261 (9th Cir. 1972).

28 Occidental Petroleum Corp. v. Buttes Gas \& Oil Co, 331 F.Supp 92, 110 (1971).

29 Buttes Gas \& Oil Co. v. Hammer (No. 3) [1982] AC 888, 935.

30 Id. at $930-31$.

$31 \quad$ Id.

32 Occidental of Umm al Qaywayn, Inc. v. A Certain Cargo Laden aboard Dauntless Colocotronis, 396 F.Supp. 461 (W.D. La. 1975).

33 Occidental of Umm al Qaywayn Inc. v. A Certain Cargo of Petroleum Laden aboard the Tanker Dauntless Colocotronis, 577 F.2d 1196, 1203 (5th Cir. 1978).

34 Baker v. Carr, 369 U.S. 186, 217 (1962).

35 Occidental of Umm al Qaywayn, Inc. v. A Certain Cargo Laden aboard Dauntless Colocotronis, 396 F.Supp 461 (W.D. La. 1975).

36 Occidental of Umm al Qaywayn Inc. v. A Certain Cargo of Petroleum Laden aboard the Tanker Dauntless Colocotronis, 577 F.2d 1196, 1203 (5th Cir. 1978). 
was impossible without an executive policy decision; ${ }^{37}$ fourthly, deciding the case would reflect a lack of respect for the executive, because the State Department had included a letter in an amicus brief, which indicated the importance of neutrality in the Middle East; ${ }^{38}$ fifthly, by implication, the political decision had been made not to declare whom the United States regarded as sovereign; and finally, by implication, there existed the potential source of embarrassment of conflicting statements from different branches of the government on the question of recognition. The State Department had not yet made a declaration in respect of sovereignty but was expected to do so in the future and the Court's ruling would be considered as detrimental to U.S. foreign policy.

This reasoning reveals twofold deference to the United States executive and to the act of state doctrine and has been criticized for violating the protection of private rights in international law. ${ }^{39}$ Here the Court was informed of the opinion of the executive, unlike the House of Lords in Buttes (No. 3). This meant it was consonant with the tradition in the United States under its separation of powers doctrine, in which the judiciary will not interfere with the executive's defined role in the constitution. The U.S. Supreme Court had, in paying such respect, denied writs of certiorari in both this and the earlier proceedings. ${ }^{40}$ The judicial approach in adopting the political question doctrine was a reflection of the doctrine of nonjusticiability in the United Kingdom. In Buttes (No. 3), Lord Wilberforce relied upon Baker to suggest that the doctrine of non-justiciability was one "starting in English law, adopted and generalised" in the law of the United States. ${ }^{41}$ The outcome of the parallel litigation in the United States on the same issues caused Lord Wilberforce in Buttes (No. 3) "to follow the Fifth Circuit Court of Appeals" in its decision and rule that the matter was non-justiciable. ${ }^{42}$

Lord Wilberforce considered that the
ultimate question [of] what issues are capable ... of judicial determination must be answered in closely similar terms in whatever country they arise ... When the judicial approach to an identical problem between the same parties has been spelt out with such articulation in a country, one not only so closely akin to ours in legal approach, the fabric of whose legal doctrine in this area is so closely interwoven with ours ... spelt out moreover in convincing language and reasoning, we should be unwise not to take benefit of it. ${ }^{43}$

This makes the judgment in the House of Lords in Buttes, as predicated upon reliance on the "political question" doctrine which is part of the U.S. constitutional separation of powers, a fact that Lord Wilberforce acknowledged but did not

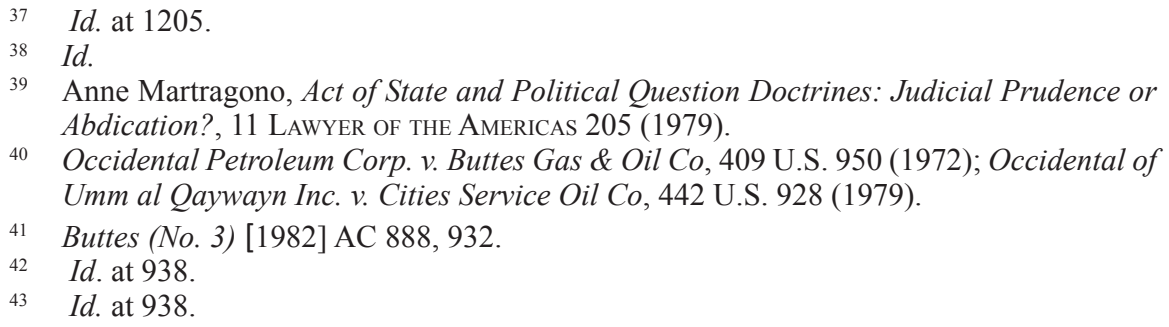


consider relevant in upholding the act of state doctrine in the English courts. ${ }^{44}$ This concurrence meant that the justiciability of cases would be the same in whatever country they arose because of its assumption that it was to be enforced in the multijurisdictional world. The rejection did not take into consideration the approach adopted in other Commonwealth states where the courts have been less hesitant in adjudicating on a matter between two private parties. ${ }^{45}$

\section{Constitutional Review of State Immunity}

The principle that existed prior to the enactment of the Justice Against Sponsors of Terrorism Act (JASTA) in 2016 was that a citizen of the United States was not entitled to recover damages from another country since the acts were those of a foreign government. The issue that the courts face is the extent to which this rule has been circumvented by the separation of powers that is a central tenet of the U.S. constitution unlike other common law systems. This has led to the emergence of the three main principles that justify this doctrine, two of which are based on the theories of "international law" and "territorial choice of law"; external deference which gained approval in the early cases establishing the political question doctrine; and the "separation of powers" theory which is based on the theory of internal deference. These are most crucial in governing the application of state immunity when denying private remedies in international law.

In Banco Nacional de Cuba v. Sabbatino (1964), ${ }^{46}$ the appellant was a Cuban corporation largely owned by U.S. residents which had contracted with an American commodity broker to buy Cuban sugar. Thereafter, subsequent to the United States government's reduction of the Cuban sugar quota, the Cuban government expropriated the corporation's property and rights. To secure consent for shipment of the sugar, the broker, by a new contract, agreed to make payment for the sugar to a Cuban instrumentality which thereafter assigned the bills of lading to petitioner, another Cuban instrumentality, and petitioner instructed its agent in New York to

$44 \quad$ Id. at $936-7$.

45 There have been references made to Baker v. Carr, 369 U.S. 186 in the High Court of Australia, however not in cases involving private international law. Rather, they have been in relation to Senate approval of legislation as in Victoria v. Commonwealth (1975) 134 CLR 81, 135 (McTiernan, J., dissenting) ('Petroleum and Minerals Authority Case'). For analysis of this judgment, see G. Lindell, The Justiciability of Political Questions, in H.P. Lee \& George Winterton (eds), Australian Constitutional Perspectives 201-02 (1992) and the level of judicial scrutiny applicable to acts of the executive and legislature. Gerhardy v. Brown [1985] HCA 11, (1985) 159 CLR 70, 138-43 (Brennan, J.); see also, Richardson v. Forestry Comm'n [1988] HCA 10; (1988) 164 CLR 261, Georgiadis v. Australian and Overseas Telecommunications Corp .- [1994] HCA 6, (9 March 1994) (Mason, C.J. \& Brennan, J.), Thorpe v. Commonwealth of Australia (No 3) [1997] HCA 21; (1997) 144 ALR 677, 692 (Kirby, J.). That these Australian references to the political question doctrine took place in cases concerning internal political considerations serves as a reminder that the political question doctrine has a wider application than the doctrine of non-justiciability, and is not confined to cases involving foreign states. For an analysis of Baker v. Carr and its potential application to Australia in respect of these internal matters, see above, at 787-96.

$46 \quad 376$ U.S. 398 (1964). 
deliver to the broker the bills of lading and sight draft in return for payment. The broker accepted the documents, received payment for the sugar from its customer, but refused to deliver the proceeds to petitioner's agent. Petitioner brought an action for conversion of the bills of lading to recover payment from the broker and to enjoin from exercising dominion over the proceeds a receiver who had been appointed by a state court to protect the New York assets of the corporation.

The district court had concluded that the corporation's property interest in the sugar was subject to Cuba's territorial jurisdiction, and acknowledged the "act of state" doctrine, which precluded judicial inquiry in the United States respecting the public acts of a recognized foreign sovereign power carried out within its own territory. The court nevertheless rendered summary judgment against the petitioner, ruling that the act of state doctrine was inapplicable when the questioned act violated international law, which the district court found had been the case. ${ }^{47}$ The U.S. Court of Appeals affirmed, additionally relying upon two State Department letters which it took as evidencing willingness by the executive branch to judicial testing of the validity of the expropriation. ${ }^{48}$ The U.S. Supreme Court held that the basis of the doctrine was not external deference but internal deference, and it concerns "a basic choice regarding the competence and function of the Judiciary and the National Executive in ordering our relationships with other members of the international community rather than laying down or reaffirming an inflexible and all-encompassing rule in this case". ${ }^{49}$

Justice Harlan's opinion in Sabbatino established the principle which is the most popular exception to the act of state doctrine that permits U.S. courts to adjudicate on the validity of foreign acts of state under international law. The international law exception originates from the concept that it would not apply if there was a "treaty or other unambiguous agreement regarding controlling legal principles" and that

\begin{abstract}
the greater the degree of codification or consensus concerning a particular area of international law, the more appropriate it is for the judiciary to render decisions regarding it, since the courts can then focus on the application of an agreed principle to circumstances of fact rather than on the sensitive task of establishing a principle not inconsistent with the national interest or international justice..$^{50}$
\end{abstract}

This prevented the courts from holding invalid an official act of expropriation by a state within its own territory which was recognized as such by the United States at the time of litigation. This was in the absence of a treaty or other undisputed agreement regarding established legal principles, even if the claim alleged that the appropriation "violates customary international law." ${ }^{1}$ The privilege of resorting to the federal courts is available to a recognized sovereign power not at war with the United States and not being dependent upon reciprocity of treatment where the 
petitioner has access to the federal courts. ${ }^{52}$ The rule is contingent on the Kirkpatrick principle, where the U.S. Supreme Court strictly limited its application to cases in which a court was required to determine the legality of a sovereign state's official acts under that sovereign's own laws.$^{53}$ Under this doctrine, the courts of one state will not question the validity of public acts performed by other sovereigns within their own borders, even when such courts have jurisdiction over a controversy in which one of the litigants has standing to challenge those acts.

The act of state doctrine will not apply merely because a judicial inquiry in the United States might humble a foreign country or interfere politically in the conduct of United States foreign policy, which are examples of the narrow application of this doctrine. The Foreign Sovereign Immunities Act of 1976 does not affect the application of the act of state doctrine. In the Restatement (Third) of the Foreign Relations Law of the United States ${ }^{54}$ which is the definitive statement of U.S. policy practice, three jurisdictional bases are confirmed which are (1) the territorial principle, (2) the nationality principle, and (3) the objective territoriality principle.

\section{EXTRATERRITORIAL JURISDICTION AND TORT LIABILITY}

In the United States there have been legal issues that have arisen in the context of domestic law within the state-federal system and these have involved the personal, territorial, and nationality jurisdictions. The federal government has promulgated several laws that govern the conduct of United States nationals abroad. These include the liability for bribing public officials of foreign countries in order to get contracts (Foreign Corrupt Practices Act of 1976) and Title VII of the Civil Rights Act also applies extraterritorially where, for example, a U.S. citizen is employed abroad by an American company.

The Alien Tort Claims Act (ATCA) 1789 may be invoked where the foreign parties are sufficiently "aliens" for the sole purpose of invoking jurisdiction of the U.S. courts. The preamble states: "The district courts shall have original jurisdiction of any civil action by an alien for a tort only, committed in violation of the law of nations or a treaty of the United States." ${ }^{55}$

$52 \quad$ Id. at 408-12.

53 In W. S. Kirkpatrick \& Co. v. Environmental Tectonics Corp., Int'l, 493 U.S. 400 (1990) the U.S. Supreme Court held that the doctrine applies 'exceptionally' and only when an action requires a declaration of invalidity of a foreign governmental act performed within its territory and does not preclude inquiry into the motivations of a foreign government. Scalia, J. held "The act of state doctrine does not establish an exception for cases and controversies that may embarrass foreign governments, but merely requires that, in the process of deciding, the acts of foreign sovereigns taken within their own jurisdictions shall be deemed valid." Id. at 409.

It implies that the courts do have a reviewing power to the extent that a case involves the "official act of a foreign sovereign," the Act of State doctrine applies only when a U.S. court must declare such an official act "invalid, and thus ineffective as a rule of decision for the courts of this country." $I d$. at 410 .

54 Published by the American Law Institute in 1987, and regularly updated, this Restatement is an unofficial yet authoritative account of international law as it applies to the United States.

55 The Act stems from the Judiciary Act in 1789 when the United States government set out it three-tiered system of courts and the U.S. Supreme Court was designated as the apex 
The Act provides civil redress in tort for a violation of established customary international law for foreign nationals against U.S. citizens. The elements that have involved legal proceedings under this Act in the American courts have concentrated on legislative intent, international law and human rights violations.

In Filártiga v. Peña-Irala, ${ }^{56}$ there was a claim by the Filártiga family, who were Paraguayan nationals, that their seventeen-year-old son, Joelito Filártiga, had been kidnapped and tortured to death in 1976 by the Inspector General of Police in Asuncion, Américo Norberto Peña-Irala (Peña). They claimed that Joelito was maltreated because his father was a longstanding opponent of the government of Paraguayan President Alfredo Stroessner. In 1978, Joelito's sister, Dolly Filártiga, and Américo Peña were both in the United States. Dolly applied for political asylum and, upon learning of Peña's presence, she reported him to the Immigration and Naturalization Service. He was arrested and ordered for deportation for staying past the expiration of his visa.

The Filártiga family filed a complaint before U.S. courts alleging that Peña had wrongfully caused Joelito's death by torture and sought compensation of $\$ 10,000,000$. The action was brought under the Alien Tort Claims Act and was intended to prevent Peña's deportation to ensure his availability for the trial process. The crimes were committed outside the United States, namely in Paraguay, and neither the plaintiffs nor the defendant were United States nationals. The District Court for the Eastern District of New York dismissed the case on the grounds that subject matter jurisdiction was absent and for forum non conveniens, ${ }^{57}$ but on appeal the Filártiga family succeeded. The U.S. Court of Appeals for the Second Circuit ruled that even though the Filártiga family did not consist of U.S. nationals and that the crime was committed outside the federal jurisdiction, the family should be allowed to bring a claim before U.S. courts. ${ }^{58}$

The main issue before the court was: does an act of torture violate the law of nations and, if a foreign national brings a case before federal courts for civil redress for acts, which occurred abroad, can this be reviewed by the courts? The U.S. Court of Appeals reversed the district court's decision, and declared that foreign nationals who are victims of international human rights violations may litigate against the perpetrators in federal court for civil redress, even for acts which occurred abroad, so long as the court has personal jurisdiction over the defendant. In particular, the Court held that "whenever an alleged torturer is found and served with process by an alien within our borders, $\S 1350$ provides federal jurisdiction". ${ }^{59}$ The Court held that "an act of torture committed by a state official against one held in detention violates established norms of the international law of human rights, and hence the

court in the land. This Act established the Judicial Courts of the United States, ch. 20, $\S$ 9, 1 Stat. 73, at 77, codified as amended as 'Alien's Action for Tort (Alien Tort Statute (ATS), Alien Tort Claims Act, (ATCA))’ 28 U.S.C. § 1350, 25 June 1948 (United States). The Judiciary Act, in its amended form, remains as the framework upon with the national court system is based. See Wythe Holt, "To Establish Justice": Politics, The Judiciary Act of 1789, and the Invention of the Federal Courts, 1989 DuKE L. J. 1421, 1478-79 (1989).

$56 \quad 630$ F.2d 876 (2d Cir. 1980),

57 Filartiga v. Peña-Irala, 577 F.Supp. 860 (E.D.N.Y. 1984).

58 Filartiga v. Peña-Irala, 630 F.2d 876, 889 (2d Cir. 1980).

$59 \quad$ Id. at 878. 
law of nations" ${ }^{60}$ It further ruled that freedom from torture is guaranteed under customary international law and the prohibition as such "is clear and unambiguous, and admits of no distinction between treatment of aliens and citizens". ${ }^{61}$

In Sosa v. Alvarez-Machain (2004), the U.S. Supreme Court stated that "any claim based on the present-day law of nations must rest on a norm of international character accepted by the civilized world and defined with a specificity comparable to the features of the 18th-century paradigms" of piracy, safe conduct, and ambassadorial offenses. ${ }^{62}$ The contemporary forms of unlawful conduct must fall within the ambit of ATCA. This is a clear direction that serves its purpose, which was defined at the time of enactment, that the federal courts had jurisdiction to hear claims in a very limited category of instances respected by the law of nations and recognized at common law. ${ }^{63}$ There have been more recent applications of the statute that have clarified the principles set out in the Act which have led the Supreme Court to determine the liability of U.S. officials or their agents in the course of claiming state immunity.

In Sosa, a U.S. Drug Enforcement Administration (DEA) special agent was abducted and then killed in 1985 by a Mexican narcotics cartel which led to an indictment being issued against Álvarez-Machaín for murder. The DEA could not convince Mexico to extradite the accused; consequently the DEA paid several Mexican nationals to seize him and transfer him to the United States. After his capture, the defense appealed to the U.S. Supreme Court, which held that the government could arraign a person who had been forcibly abducted, but that the capture might violate international law and provide grounds for civil litigation. ${ }^{64}$

The case was remitted back to the district court for trial where ÁlvarezMachaín was found not guilty for lack of evidence. In 1993, after returning to Mexico, Alvarez filed civil actions against Sosa, Mexican citizen and DEA operative

Id. at 880 .

Id. at 884 .

62 Sosa v. Alvarez-Machain, 542 U.S. 692, 724-25 (2004).

63 See, Karen E. Holt, Filartiga v. Pena-Irala after Ten Years: Major Breakthrough or Legal Oddity?, 20 GA. J. of INT'L \& Comp. L. 543 (1990) Beth Van Schaack, The Story Behind the Case that Launched a Legal Revolution: A Review of William Aceves's The Anatomy of Torture - A Documentary History of Filartiga v. Pena-Irala', Hum. R'Ts Q. 1, (2008); James Paul George, Defining Filartiga: Characterizing International Torture Claims in United States Courts, 3 Dickinson J. of InT'L L. 1 (1984); Laura Dickinson, Filartiga's Legacy in an Era of Military Privatization, 37 RuTGERS L.J. 703 (2006); Gabriel M. Wilner, Filartiga v. Pena-Irala: Comments on Sources of Human Rights Law and Means of Redress for Violations of Human Rights, 11 GA. J. OF INT'L \& Com. L. 317 (1981); Daniel S. DoKos, Enforcement of International Human Rights in the Federal Courts after Filartiga v. Pena-Irala, 67 VA. L. Rev. 1379 (1981); W.J. Aceves, The Anatomy of Torture: A Documentary History of Filartiga v. Pena-Irala (2007); Dean Rusk, Comment on Filartiga v. Pena-Irala, , 11 GA. J. of INT'L \& Com. L. 311 (1981); Anutosh Pandey, An Assessment of Filartiga v. Pena-Irala , NAT'L L. UnIV., OrISSa (NLUO) 1 (2012); Beth Stephens, Translating Filártiga: A Comparative and International Law Analysis of Domestic Remedies for International Human Rights Violations, 27 Y ALE J. OF INT'L L. 1 (2002); Jr. C. Donald Johnson, Filartiga v. Pena-Irala: A Contribution to the Development of Customary International Law by a Domestic Court, GA. J. OF INT'L \& Comp. L. 335 (1981). 
Antonio Garate-Bustamante, five unnamed Mexican civilians, the United States, and four DEA agents.

This was under the Federal Tort Claims Act (FTCA), which allows the federal government to be sued on tort claims, and ATCA, which permits law suits against foreign citizens in American courts. The United States government argued that the FTCA applied only to claims arising from actions within the domestic jurisdiction of the United State and, therefore, did not apply to the plaintiff because his arrest took place in Mexico. The federal authorities and the Mexican nationals also stated that the ATCA permitted federal court jurisdiction to decide tort claims against foreign citizens, but did not permit private individuals to commence actions. The federal district court disagreed with the government's contention that the FTCA claim did not apply, finding that the plan to capture Alvarez-Machain was instigated within the U.S. jurisdiction. ${ }^{65}$

They exonerated the federal party by stating that the DEA had acted lawfully when the arrest happened, and also vindicated the litigation by private individuals under ATCA by holding that Sosa, one of the Mexican nationals who kidnapped Álvarez-Machaín, had violated international law and was liable. On appeal, the Ninth Circuit overruled the decision that the federal party was not liable under the FTCA decision, because the DEA could not authorize a citizen's arrest of the accused in another country. It affirmed the lower court's finding on the ATCA claim that Sosa was liable in the detention of Alvarez-Machain. This judgment confirms that the provisions of ATCA enable an "alien" plaintiff to file a tort claim against any person over whom the U.S. government has personal jurisdiction, regardless of whether the defendant is a citizen or a foreign national and regardless of whether the alleged tort occurred within or extra-territorially. The provisions of the Act do not prescribe substantive law but require the federal courts to recognize any tort that infringes on individual rights granted by international law. ${ }^{66}$

The availability of such a remedy means that the Act is a jurisdictional statute that addresses a set of justiciable torts limited to those defined as prohibited norms under either the law of nations or treaties adopted by the United States. The law of nations covers only that part of international law which can be defined as the core set of norms universally binding on States. This means that there has to be a recognition of rights enshrined as part of the "law of nations". The ruling also established an elastic framework for determining which torts constitute causes of action under its clauses. The clauses of ATCA do not contain any locus delicti restriction on the exercise of jurisdiction but $\$ 2680(\mathrm{k})$ of the Judiciary Act (its parent statute ) does. ${ }^{67}$ This section provides an exception to the waiver of sovereign immunity provided

65 See summary of proceedings in Alvarez-Machain v. U.S., 331 F.3d 604, 610 (9th Cir, 2003).

66 Alvarez-Machain v. U.S., 331 F.3d 604 (9th Cir, 2003). The rules most likely to have that status would be specific rules protecting basic human rights, such as the rule against torture or the rule against cruel, inhuman or degrading treatment. For the debate on whether international human rights law is part of federal law, compare Curtis A. Bradley \& Jack L. Goldsmith, The Current Illegitimacy of International Human Rights Litigation, 66 Fordham L. Rev. 319 (1997) with Harold Hongju Koh, Is International Law Really State Law?, 111 Harv. L. Rev. 1824 (1998).

6728 U.S.C. $\S 2680(\mathrm{k})$. "The provisions of this chapter and $\S 1346(\mathrm{~b})$ of this title [that waive sovereign immunity and include the ATCA] shall not apply to: . . . (k) Any claim arising in a foreign country." 
by the ATCA and which proved fatal to the claim in $S_{0 s} a^{68}$ as the term "alien", when construed by the framers of ATCA, premised it on a political identity based on affiliation and the jurisdiction of other sovereigns. If this argument prevails then there needs to be a determination of how high the standard must be to recognize a cause of action for a violation of the law of nations; as a domestic matter there would be no "potential implications" for foreign relations. ${ }^{69}$

For the United States, the point of departure with other common law jurisdictions concerns obligations under treaties which are the highest source of power in the land and which bind the courts to respect them as the law of nations. ${ }^{70}$ It remains settled law in the United States that courts should not construe a statute to violate international law if any other plausible construction presents itself. In Murray v. Schooner Charming Betsy, 6 U.S. 64, 118 (1804). Chief Justice Marshall wrote that "an act of Congress ought never to be construed to violate the law of nations if any other possible construction remains." $" 71$ Thus, American judges remain under a duty to avoid, if at all possible, placing the United States in breach of its international obligations. The issue that concerns the courts only involves natural persons; claims where plaintiffs and/or defendants are entities, and those against the corporations, governments, etc., are not justiciable under the Act. There is also the consideration that the court does not address the asymmetry of rights, whereby alien plaintiffs can avail themselves of a right under the ATCA (i.e., federal rather than state jurisdiction over tort damages of any amount) that ordinary citizens of the United States cannot invoke. ${ }^{72}$

There has since been affirmation of the common law principles by the U.S. Supreme Court which has held that they override the statute in claims of immunity

68 Sosa v. Alvarez-Machain, 542 U.S. 692, (2004) - "The actions in Mexico are thus most naturally understood as the kernel of a claim 'arising in a foreign country,' and barred from suit under the exception to the waiver of immunity." at 700-01.

69 Id. at 727-28. "[T] he subject of those collateral consequences is itself a reason for a high bar to new private causes of action for violating international law, for the potential implications for the foreign relations of the United States of recognizing such causes should make courts particularly wary of impinging on the discretion of the Legislative and Executive Branches in managing foreign affairs." Indeed, the executive and legislative branches have set a clear, long-standing policy of self-determination, but the courts remain hostile.

70 The Supremacy Clause of Article VI, cl. 2 of the United States Constitution provides that "This Constitution, and the Laws of the United States which shall be made in Pursuance thereof; and all Treaties made, or which shall be made, under the Authority of the United States, shall be the supreme Law of the Land".

716 U.S. 64, 118 (1804).See also Sale v. Haitian Ctrs. Council, Inc., 509 U.S. 155, 178 n.35 (1993) (affirming application of Charming Betsy canon to all matters of federal statutory construction).

72 Referring to civil law countries like Belgium, Justice Breyer's concurrence in Sosa v. Alvarez-Machain explains that universal criminal jurisdiction necessarily contemplates civil recovery:

$[\mathrm{C}]$ onsensus as to universal criminal jurisdiction itself suggests that universal tort jurisdiction would be no more threatening. That is because the criminal courts of many nations combine civil and criminal proceedings, allowing those injured by criminal conduct to be represented, and to recover damages, in the criminal proceeding itself.

Sosa v. Alvarez-Machain, 542 U.S. 692, 762 (2004). 
by individual foreign officials. In Samantarv. Yousuf, $(2010)^{73}$ the plaintiffs, who were of Somalian origin, filed a case against Mr Samantar, a former official of a Somali regime in a Virginia federal district court under the Torture Victim Protection Act ("TVPA") and the Alien Tort Statute ("ATS"). They alleged that they were victims of torture and other human rights violations while the defendant commanded agents of the former Somali government. The district court dismissed the case, holding that Mr. Samantar was immune from suit under the Foreign Sovereign Immunities Act ("FSIA").

The U.S. Court of Appeals for the Fourth Circuit reversed, holding that the FSIA did not render Mr. Samantar immune from suit on the basis that it did not apply to foreign government officials. ${ }^{74}$ The court stated that even if the FSIA does apply to foreign government officials, it does not apply to former foreign government officials. This raised the issue, firstly, whether a foreign state's FSIA immunity from suit extend to an individual acting in his official capacity on behalf of the foreign state and, secondly, whether an individual who is no longer a government official of a foreign state when litigation is commenced retains FSIA immunity for acts carried out in that individual's former capacity as a government official acting on behalf of a foreign state.

The Supreme Court held that the FSIA did not govern Samantar's claim of immunity and that there was no inference within the Act to suggest that "foreign state" should be read to include an official acting on behalf of that state. The Court also stated that the intention of Congress in the Act did not express the intention to codify official immunity within the FSIA. Justice Stevens writing his opinion for the court held that the FSIA's provisions - i.e. $\$ 1603(\mathrm{a})$ — did not mean to include the 'foreign state' to include foreign officials. ${ }^{75}$ In the circumstances where the respondents have sued petitioner in his personal capacity and seek damages from his own resources the proceedings are "governed by the common law because it is not a claim against a foreign state as defined by the FSIA". ${ }^{76}$

Stewart reflecting on this ruling states

\begin{abstract}
"Human rights advocates might generally be pleased that individual officials can no longer claim immunity under the FSIA. But nothing in the decision signals open season for suits against such officials. Significant issues remain to be litigated, among them whether the Torture Victim Protection Act of 1991 (which creates a civil cause of action against any individual who under actual or apparent authority, or color of law, of any foreign national subjects an individual to torture or extrajudicial killing) reflects congressional intent to override the common law of foreign official immunity". ${ }^{77}$
\end{abstract}

The litigation in the United States covering extraterritorial claims has proceeded governed by the ATS, as long as the tort claimants have a strong connection with the territory of the US and their claims are sufficiently compelling. In Kiobel v. Royal Dutch Petroleum Co. $(2013)^{78}$, the plaintiffs were Nigerian citizens who

560 U.S. 305 (2010).

552 F. 3d 371 at 381-83.

Samantar v. Yousuf, 560 U.S. 305, 319 (2010).

Pp. 13-19.

77 David P. Stewart, Samantar v. Yousuf: Foreign Official Immunity Under Common Law, 14 (15) Am.Soc. InTN'L Law,Insights, (June 14, 2010), https://www.asil.org/insights/ volume/14/issue/15/samantar-v-yousuf-foreign-official-immunity-under-common-law.

78 Kiobel v. Royal Dutch Petroleum Co., 569 U.S. 108 (2013). 
had been subjected to human rights violations in Nigeria committed by Nigerian security forces in the 1990s. The issue was whether the Nigerian subsidiaries of the defendants - Royal Dutch Petroleum Co. of the Netherlands and Shell Transport and Trading Company PLC of the United Kingdom - assisted the commission by the Nigerian security forces of acts of torture, extrajudicial execution, and arbitrary detention. The only connections to the United States, apart from plaintiffs' current residence, were the parent corporations' investor registration in New York. The Supreme Court had to decide whether the extraterritoriality of the alleged acts of abuse brought them within the jurisdiction of the federal courts. The question of the application of the ATCA was based on the precedent of Sosa that established it was intended to enforce international norms and civil tort actions inferring that violations of the law of nations should determine the scope of the statute. The majority opinion delivered by Chief Justice Roberts noted that all the relevant conduct took place outside the United States, and that even where the claims affected the territory of the United States, they did not impact with "sufficient force to displace the presumption against extraterritorial application". ${ }^{79}$ The corporate presence was not restricted to presence in the U.S. jurisdiction.

Justice Breyer provided the minority opinion concurring with the decision and stated that there should be jurisdiction under the act

where (1) the alleged tort occurs on American soil, (2) the defendant is an American national, or (3) the defendant's conduct substantially and adversely affects an important American national interest, and that includes a distinct interest in preventing the United States from becoming a safe harbor (free of civil as well as criminal liability) for a torturer or other common enemy of mankind. ${ }^{80}$

He founded this belief on the precedent established in Sosa where the Court had held that ATCA provided federal courts with jurisdiction for a small number of claims that rested on a "norm of international character accepted by the civilized world and defined with a specificity comparable to the features of the 18th-century paradigms we have recognized". ${ }^{81}$ However, the Court affirmed that "only conduct that satisfies Sosa's requirements of definiteness and acceptance among civilized nations can be said to have been "the 'focus' of congressional concern". ${ }^{82}$ The ATCA cause of action will fall within the scope of the presumption against extraterritoriality and will therefore be barred unless those claims "touch and concern the territory of the United States" with "sufficient force." 83

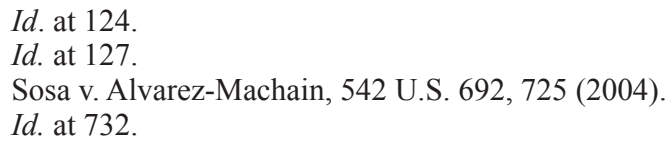

Kiobel v. Royal Dutch Petroleum Co, at 1669. For objections to the Court's presumption against the ATS's extraterritorial applicability, see Kiobel, 133 S. Ct. at 1672 (Breyer, J., concurring); Anthony J. Colangelo, The Alien Tort Statute and the Law of Nations in Kiobel and Beyond, 44 Geo. J. InT'L L. 1329 (2013); Anthony J. Colangelo, Kiobel: Muddling the Distinction Between Prescriptive and Adjudicative Jurisdiction, $28 \mathrm{MD}$. J. INT'L L. 65 (2013); Jonathan Hafetz, Human Rights Litigation and the National Interest: Kiobel's Application of the Presumption Against Extra-Territoriality to the Alien Tort 
Justice Alito, concurring, noted the Court's earlier holding in Sosa that "federal courts should not recognize private claims under federal common law for violations of any international law norm with less definite content and acceptance among civilized nations than the historical paradigms familiar when [the ATS] was enacted." 84 This implies the "conduct that satisfies Sosa's requirements of definiteness and acceptance among civilized nations can be said to have been "the 'focus' of congressional concern". The cause of action will fall within the "scope of the presumption against extraterritoriality — and will therefore be barred — unless the domestic conduct is sufficient to violate an international law norm that satisfies Sosa's requirements of definiteness and acceptance among civilized nations" ${ }^{85}$

Paul Hoffman, who argued both Sosa and Kiobel in the Supreme Court, considers that the Kiobel presumption will be the main initial "screening mechanism" for claims arising under the Act and will influence the approach of the courts regardless of the manner of its interpretation. He states that "it is unclear how the Kiobel majority views the relationship between the new presumption and existing limiting doctrines (e.g. forum non conveniens, political questions, international comity) commonly litigated in ATS cases". ${ }^{86}$ It could mean that this ruling will become the final reference whenever the courts are unable to rule on the basis of traditional screening doctrine and that they will have to develop a methodology to interpret the case law. The question that will be relevant is whether, as in Sosa, the court will apply a number of limiting principles that refer to ATCA including a sufficiently definite international norm, exhaustion of remedies outside the United States, and a policy of facts-specific deference to the political branches of the constitution. The result of the case is that it is now impossible to predict the presumptions of future applications.

\section{E. IMPACT OF JASTA ON STATE IMMUNITY}

The Justice Against Sponsors of Terrorism Act (JASTA) 2016, enacted by the U.S. Congress over President Obama's veto, creates a subject matter jurisdiction for courts to hear cases that involve alleged wrongdoing by other countries. It amends the Foreign Sovereign Immunities Act (FSIA), which had no direct bearing on the content of any lawsuit, but articulates a few narrow instances in which lawsuits against foreign countries may proceed in federal court. It had a terrorism exception that was limited to designated state sponsors of terrorism. ${ }^{87}$ JASTA amends existing legislation by providing a means to litigate civil claims based on tort for acts related

Statute, 28 MD. J. InT'L L. 107 (2013); David Sloss, Kiobel and Extraterritoriality: A Rule Without a Rationale, 28 MD. J. INT’L L. 241 (2013).

84 Id. at 126.

85 Id. at 127 (Alito J. concurring).

86 Paul L. Hoffman, Kiobel v. Royal Dutch Petroleum Company: First Impressions, 52 Colum. J. of Transnt'L L. 28, 41 (2013).

87 This exception in the FSIA has existed since 1996, under 28 U.S.C. $\S 1605 \mathrm{~A} . \S 1605 \mathrm{~A}$ provides that a foreign state shall not be immune from suits seeking money damages for personal injury or death caused by certain acts like torture and extrajudicial killing — or material support for such acts - by foreign government officials. This provision is limited to countries designated by the United States as state sponsors of terrorism (currently Iran, Sudan, and Syria). 
to terrorism. ${ }^{88}$ The federal courts will be able to hear claims against any sovereign nation that "knowingly or recklessly contribute material support or resources, directly or indirectly, to persons or organizations that pose a significant risk of committing acts of terrorism." 89

The new terrorism exception added by JASTA under $\S 1605 \mathrm{~B}$ provides that a foreign state shall not be immune from suits seeking money damages for personal injury or death, or for injury to property, occurring in the United States that is caused by (1) an act of international terrorism in the United States; and (2) a tortious act of a foreign state or its officials "regardless where the tortious act or acts of the foreign state occurred." ${ }^{90}$ The tortious act of a foreign state may not, however, be an omission or "constitute mere negligence." or commenced on or after, the date of enactment of JASTA; and arising out of an injury to a person, property, or business on or after September 11, 2001. Unusually Section 7 states that the Act applies retrospectively.

Prior to JASTA, a U.S. national could not litigate an action based on an act of international terrorism against "a foreign state, an agency of a foreign state, or an officer or employee of a foreign state or an agency thereof acting within his or her official capacity or under color of legal authority." ${ }^{22}$ By enacting JASTA, the Congress has ensured that a U.S. national may now bring an action in federal courts for claims against a foreign state seeking money damages for physical injury to a person or property or death that occurs inside the United States, and caused by an act of international terrorism in the United States; the tortious act or acts of the foreign state, or of any official, employee, or agent of that foreign state while acting within the scope of his or her office, employment, or agency, regardless where the tortious act or acts of the foreign state occur..$^{93}$ The act or acts have to be more than mere negligence. ${ }^{94}$

There has been criticism of JASTA in the light of the erosion of the principle of sovereign immunity. There have been criticisms levelled in European parliaments to the effect that JASTA "conflict[s] with fundamental principles of international law and in particular the principle of State sovereign immunity." 95 This is premised on the fact that state immunity is a rule of customary international law that recognizes foreign sovereign immunity in some circumstances in respect of torts committed by

88 Since the U.S. Supreme Court's decision in Argentine Republic v. Amerada Hess Shipping Corp., 488 U.S. 428 (1989), the tort exception has been interpreted as applying only where both the tort was committed in the United States and the resulting injury occurred in the United States. This "entire tort rule" was applied to dismiss actions brought against certain foreign state instrumentalities that the plaintiffs alleged had assisted with the September 11th attacks. In In re Terrorist Attacks on September 11, 2001, 714 F.3d 109, 116-17 (2d Cir. 2013), the alleged tortious conduct occurred outside the United States; however, the court found that the entire tort rule barred the suit.

$89 \quad 18$ U.S.C. $\$ 2337$.

$90 \quad 28$ U.S.C. $\S 1605 \mathrm{~B}(\mathrm{~b})(2)$.

9128 U.S.C. $\S 1605 B(d)$.

$92 \quad 18$ U.S.C.A. $\$ 2337(2)$

9328 U.S.C. $\$ 1605 \mathrm{~B}(\mathrm{~b})$.

$94 \quad 28$ U.S.C. $\$ 1605 B(d)$.

95 Julian Pacquet, EU Lawmakers Warn Congress against Saudi Terrorism Bill, ALMonitor, 13 July 2016. http://www.al-monitor.com/pulse/originals/2016/07/europeanwarn-congress-saudi-terrorism-bill-jasta-911.html\#ixzz4OIVbVkWd. 
armed forces during an armed conflict. ${ }^{96}$ This establishes certainty in the customary international law rules of immunity that must be based upon a general and consistent practice of states followed out of a sense of legal obligation or opinio juris. ${ }^{97}$

However, the United States, like many other common law-based jurisdictions, follows a restrictive theory of foreign sovereign immunity under which the immunity of foreign states does not extend to their private and commercial acts (acta jure gestionis), but generally does extend to their governmental acts (acta jure imperii). ${ }^{98}$ The International Court of Justice (ICJ) has also not assiduously demarcated the difference between immunity and lack of immunity between governmental and non-governmental acts. The only certainty in its judgment is related to armed forces during war, leaving open the question whether other governmental acts might not be covered by immunity. ${ }^{99}$ This may refer to terrorism or providing material support for acts of terrorism which, if properly considered governmental, may not necessarily entitle those acts to immunity under international law.

The scope of the FSIA and the actions against the governments and their assets deemed to have been sponsors of terrorism has been determined in a recent judgment delivered by the U.S. Supreme Court in Rubin v. Islamic Republic of Iran (2018) ${ }^{100}$. The legal proceedings were based on a ruling that the petitioners had obtained against the respondent Islamic Republic of Iran under the $\S 1605 \mathrm{~A}$ of the Act as a designated state sponsor of terrorism and had locus standi with respect to claims arising out of acts of terrorism. To enforce that judgment, they filed an action in the district court to seize and appropriate certain Iranian assets, namely antiques housed at the University of Chicago. This was rejected at first instance based on the immunity granted to a foreign state and the Seventh Circuit affirmed. ${ }^{101}$ The Supreme Court upheld the ruling and stated unanimously that there was "no freestanding exception to property immunity in the context of a FSIA exception under the Section $1610(\mathrm{~g})$ to attach and execute against the property of a foreign state". ${ }^{102}$

However, Professor William S. Dodge argues that in validating the JASTA's new terrorism exception there appears to be no general and consistent practice of states or opinio juris that establishes a "legal obligation that foreign states are entitled to immunity for acts of terrorism or material support of such acts. To be sure, most states that have statutes governing foreign sovereign immunity do not have exceptions for terrorism. But it is not clear that the states extending foreign sovereign immunity to cover terrorist acts do so out of a sense of legal obligation". He points to both the United States and Canada that have "terrorism exceptions in their foreign sovereign immunity laws" and the "lack of protests prior to JASTA is more evidence that a terrorism exception does not violate customary international law". The liability for breaching the provisions in both the United States and Canada relate to the "state sponsors of terrorism". ${ }^{103}$

\footnotetext{
96 Jurisdictional Immunities of the State (Germany v. Italy: Greece intervening), Judgment, I.C.J. Rep. 99, 178 (2012).

$97 \quad I d$. at 955.

$98 \quad I d$. at 964

99 Id. at 65.

100 Rubin v. Iran, 583 U.S. (2018).

101830 F.3d 470 (7th Cir. 20177).

102 Rubin v. Iran, No. 16-534, slip op. at 12-15 (Feb. 21, 2018).

103 William S. Dodge, Just Security, Does JASTA Violate International Law? (Sept. 30, 2016) -https://www.justsecurity.org/33325/jasta-violate-international-law-2/.
} 
However, Dodge states that the "foreign sovereign immunity typically turns on the nature of the act, and international law does not typically dictate the particular processes a state must use to grant or deny such immunity". It is not contingent on the customary international law for "the U.S. and Canada to deny foreign sovereign immunity when they have designated a particular country as a state sponsor of terrorism". The reason is that "customary international law does not require foreign sovereign immunity for terrorist acts in the first place". In determining whether state immunity for terrorism sponsorship can be deemed as parallel to foreign sovereign immunity with respect to armed forces, Dodge sees a precedent in Jurisdictional Immunities, where the ICJ found for armed forces "an almost unbroken practice of judicial decisions extending such immunity, even when the acts were committed on a state's own territory". ${ }^{104}$ There is no comparable "unbroken practice of forum states extending immunity to foreign states that provide support for terrorist acts causing injury and death within the forum state". ${ }^{105}$

U.S. courts, before JASTA was enacted, had adopted an "entire tort" interpretation of the FSIA territorial tort exception under 1605 (a)(5), requiring that not just the injury but also all of the tortious conduct should have occurred in the United States. However, Article 12 of the proposed United Nations Convention on Jurisdictional Immunities of States and Their Properties ${ }^{106}$, for example, would apply the territorial tort exception if the act or omission occurred "in whole or in part" in the territory of the state exercising jurisdiction. This implies that the U.N. Convention would dispense compensation with regards to immunity, rather than enforce it as customary international law requires.

There are various processes by which sovereign immunity may be preserved. Section 5(b) permits the U.S. Attorney General to intervene in any action being taken against a foreign state "for the purpose of seeking a stay of the civil action, in whole or in part." The U.S. court "may stay a proceeding against a foreign state if the Secretary of State certifies that the federal government is engaged in good faith discussions with the foreign state defendant concerning the resolution of the claims against the foreign state, or any other parties as to whom a stay of claims is sought." 107 There may be several 9/11-related suits likely to be filed and it remains to be seen how often, and in what circumstances, an intervention is made by the Department of Justice. There may also be diplomatic, legal, and judicial repercussions and demands made upon the United States for the collateral damage caused by U.S. servicemen, representatives or agencies. ${ }^{108}$

104 Id. (citing Jurisdictional Immunities of the State (Germany v. Italy: Greece intervening), Judgment, I.C.J. Rep. 99, $₫ \uparrow 773-77$ (2012)).

105 Id.

106 U.N.G.A. A/RES/59/38 (Dec 2, 2004) (not yet entered into force).

107 JASTA $\S 5$.

108 There have been suggestions by an Iraqi lobby group that the United States should pay compensation for damages arising out of the 2003 invasion. See, e.g., Juliet Eilperin \& Karoun Demirjian, Congress Thwarts Obama on Bill Allowing 9/11 Lawsuits Against Saudi Arabia, Washington Post (Sept. 28, 2016). 


\section{CANADA}

\section{A. SoVEREIGN ImMUNity IN LAW}

In comparing the issue of justiciability in the Canadian courts with the American "political question" doctrine, state immunity needs to be considered within the context of recent statutes and case law. The Canadian government has, like the other common law countries, enshrined the principle of state immunity into its statutory framework. ${ }^{109}$ The State Immunity Act (SIA) has been upheld as a complete solution to any claim against immunity, trumping countervailing theories of implied exceptions that may exist elsewhere under the common law or international law. ${ }^{110}$ The law of sovereign immunity under the SIA has been recognized by the courts in Canada as giving effect to the customary rules of international law. ${ }^{111}$ The Canadian courts recognize that state immunity represents important issues of comity and mutual respect between nations. ${ }^{112}$

Section 3(1) states "[e]xcept as provided by this Act, a foreign state is immune from the jurisdiction of any court in Canada". Under a plain and ordinary reading, these words codify the law of sovereign immunity. In Canada, international treaties must be incorporated into domestic law through adoption before they have domestic force and effect. ${ }^{113}$ Customary law, on the other hand, is presumed to be directly incorporated into domestic law unless explicitly altered by contrary legislation. ${ }^{114}$ SIA governs civil claims against foreign states and Canadian courts recognize that state immunity represents important issues of comity and mutual respect between nations. However, in cases where Canadian nationals have been tortured by a foreign state, there has been recourse to the courts where state immunity has been pleaded. ${ }^{115}$

109 State Immunity Act, R.S.C. 1985, as amended 2012. c. S1-18 (the "SIA").

110 The Supreme Court in Re Canada Labour Code, [1992] 2 S.C.R. 50, held the Act to be a codification of Canadian law regarding foreign immunities ( $₫$ 69).

111 See generally, John H. Currie, Perspectives on State and Diplomatic Immunity, CounTY of Carlton Law Assoc. Update on Civ. Lit., (2001); and Hazel Fox, The Law of State IMMUNITY (2002).

112 Schreiber v. Canada (Attorney General) (2002), 216 D.L.R. (4th) 513 (S.C.C.), ๆ 27.

113 Upon ratifying an international agreement, Canada will have international obligations flowing from that agreement that remain unchanged despite a failure to enact implementing legislation or otherwise make the agreement domestically binding. See Ahani v. Canada (Attorney General) 58 OR (3d) 107, \ 32 [2002] (Ontario Court of Appeal). The majority decision was set out with reasons but, in a highly unusual move, Heureux-Dube, J. expressed dissent from the other two judges on the appeal panel. Id. at 962.

114 On the importance of customary international law for Canadian legislation generally, see 114957 Canada Ltée (Spraytech, Société d'arrosage) v Hudson (ville) 2001 SCC 40, \28-32. For a discussion of the application and incorporation of international law generally in Canada, see: Jutta Brunnée \& Stephen J. Toope, A Hesitant Embrace: The Application of International Law by Canadian Courts, 40 CANADIAN Y'BOOK OF INT'L L. 3 (2002).

115 "While human rights norms have been accumulating at a rapid pace since the end of the Second World War, the development of institutional mechanisms of enforcement has not tracked these advances. [...] The result is an enforcement gap which leaves many individuals in the untenable position of possessing rights without remedies"- see Wendy 
In Bouzari v. Islamic Republic of Iran, (2004), a case brought by an Iranian immigrant, who was tortured by government officials in his home country, led to the Ontario Court of Appeal dealing with the question of whether the SIA provides potential remedies for victims of torture abroad. The facts in the case demonstrated that Ontario was the only place where Mr. Bouzari could sue and, as in many such cases for victims of torture, it was impossible for Mr. Bouzari to return to the country whose government agents had tortured him in order to lodge a legal claim against the state. ${ }^{116}$

The Court decided that existing Canadian law precludes claims against foreign sovereigns for such acts. Goudge, J.A. ruled that

the wording of the SIA must be taken as a complete answer to this argument. Section 3(1) could not be clearer. To reiterate, it says: "3(1) Except as provided by this Act, a foreign state is immune from the jurisdiction of any court in Canada." The plain and ordinary meaning of these words is that they codify the law of sovereign immunity. ${ }^{117}$

The Bouzari Court concluded that the SIA occupies the field in this area and that it provides no exception for torture. The outcome in this case suggests, therefore, that civil redress in Canadian courts for grave human rights abuses committed by foreign states will be driven by legislative change, not an expansive interpretation of the existing Act. ${ }^{118}$

The Canadian courts recognize a difference between forms of international law and treaties must be incorporated into domestic law through a formal act of parliament before they have domestic force and effect. ${ }^{119}$ Customary law, on the other hand, is presumed to be directly incorporated into domestic law unless explicitly altered by contrary legislation. ${ }^{120}$ To the extent that an act of torture constitutes a violation of customary law, Canadian courts may presume a violation of domestic law unless that presumption is refuted by a statute or treaty. However, this implied waiver approach first gained prominence in the United States and is a cousin to the normative hierarchy theory. ${ }^{121}$ This approach implies that state immunity is a

Adams, In Search of a Defence of the Transnational Human Rights Paradigm: May Jus Cogens Norms be Invoked to Create Implied Exceptions in Domestic State Immunity Statutes? in Craig Scott (ed.), Torture as Tort 250 (2001).

116 Bouzari v. Iran [2004] OJ No 2800, ๆ 42 (Ontario Court of Appeal).

117 Id.

118 See also, Arar v. Syria [2005] O. J. No. 752, \ 28.

119 Upon ratifying an international agreement, Canada has international obligations flowing from that agreement that remain unchanged despite a failure to enact implementing legislation or otherwise make the agreement domestically binding. Ahani v. Canada (Attorney General) 58 O.R. (3d) 107, 2002 O.J. No. 431, \ 32; (Leave to appeal to the Supreme Court den'd, [2002] S.C.C.A. No. 62).

120 Bouzari v. Iran [2004] OJ No 2800 , 95 ; On the importance of customary international law for Canadian legislation generally, see 114957 Canada Ltée (Spraytech, Société d'arrosage) v. Hudson (ville) 2001 SCC 40, 200 D.L.R. (4th) 419, ๆ व 28-32. For a discussion of the application and incorporation of international law generally in Canada, see: Jutta Brunnée \& Stephen J. Toope, A Hesitant Embrace: The Application of International Law by Canadian Courts, 40 CANAdian Y'BOoK of InT'L L. 3 (2002).

121 See generally, Lee M. Caplan, State Immunity, Human Rights, and Jus Cogens: A 
privilege granted to states as members of the international community of nations and intended to encourage the comity of nations. However, if a state acts contrary to its international legal expectations and violates prohibitions of international jus . cogens, it cannot then claim the privilege of immunity for those acts. ${ }^{122}$ The offending state, by disregarding peremptory norms of international law, has waived its rights under international law to the extent that those rights conflict with its illegal actions.

\section{B. MERITS-BASED APPROACH}

The implication for the sovereign immunity is that the Canadian judiciary has not defined the powers of judicial review by restricting them to just sovereignty and territoriality. This is a clear basis for review by the courts for private litigants, which can bring private claims for tortious liability and the review will be the process of a merits-based approach. The merits-based approach has an advantage in that it is a more appropriate procedure for those seeking judicial resolution of disputes. It makes the courts more accessible for litigants who should anticipate that their claims may only fail for legal reasons. These litigants will not be dismissed because state immunity will not apply and the failure to use, and the abuse of, executive certificate standards or concerns not to infringe the executive's role will not prevent the court's intervention.

In Operation Dismantle Inc. v. R. [1985] 1 SCR 441, the Supreme Court of Canada unanimously dismissed an appeal against a decision to strike out a statement of claim which alleged that the Canadian executive's decision to allow the United States to test cruise missiles in Canada increased the likelihood that Canada would be a target for nuclear attack, thereby violating the right to life, liberty and security of the person under the Canadian Charter of Rights and Freedoms (Section 7, Part I of the Constitution Act 1982). ${ }^{123}$ The judgment seemed to imply that the question presented to the Court was by no means non-justiciable; however, there was no reference to Buttes Gas \& Oill ${ }^{124}$ in the ruling even though this decision was contemporaneous with the House of Lords case. Nor did Operation Dismantle draw on Lord Wilberforce's reasoning that defined the parameters of when the act of state doctrine will not apply, such as where there will be a "breach of clearly established rules of international law or are contrary to English principles of public policy, or where there is a grave infringement of human rights". ${ }^{125}$

Wilson, J. explicitly rejected the "political question" doctrine and instead stated there was a concept of abstention, and focused on "whether the courts should

Critique of the Normative Hierarchy Theory, 97 Am. J. InT'L L. 41 [2003]; Adam C. Belsky et al., Implied Waiver Under the FSIA, 77 CAL. L. REV. 365 (1989).

122 Adam Day defines the normative rights theory as 'International law cannot bestow immunity from prosecution for acts that the same international law has universally criminalized'. See Adam Day, Crimes against Humanity as a Nexus of Individual and State Responsibility: Why the ICJ Got Belgium v. Congo Wrong, 22 Berkeley J. of InT'L L. 489 (2004).

123 Operation Dismantle Inc. v. R. [1985] 1 SCR 441.

124 Buttes Gas \& Oil Co. v. Hammer (No. 3) [1982] AC 888.

125 Kuwait Airways Corp. v. Iraqi Airways Co. (No's 4 \& 5) [2002] UKHL 19, ๆ 148. 
or must rather than on whether they can deal with such matters". ${ }^{126}$ Wilson, J. held that courts should not relinquish their judicial review function simply because a case involves a "weighty" matter of state and it is not available to a court to surrender jurisdiction "on the basis that the issue is inherently non-justiciable, or that it raises a so-called political question". ${ }^{127}$ This determination was based on the constitutional determination that balanced the principles of the "separation of powers, responsible government and the rule of law which obviate the need for a doctrine of abstention". ${ }^{128}$ She ruled that, in Canadian constitutional law, separation is not a core principle, but is rather of secondary application and there is an overlap between the branches as demonstrated in the system of responsible government. ${ }^{129}$

Dickson, J. dismissed the appeal on its merits, declaring that the appellants could never prove the causal link between the government's decision to permit testing and the increased likelihood of a nuclear war. The foreign policy decisions of other nations were thought not to be capable of forecasting "to any degree of certainty approaching probability" and would remain based on speculation. ${ }^{130}$ The judgment analysed the claim for its plausibility rather than opposing it based on an abstract notion of judicial restraint. It gave weight to the allegation that development of the cruise missile would lead to an escalation of the nuclear arms race but found that to be too hypothetical. However, it could equally be alleged that development of the cruise missile might compel foreign powers to negotiate agreements that would reduce the threat of a nuclear war. ${ }^{131}$

In terms of stating principles, the joint judgment stated obiter, that there is "no doubt that disputes of a political or foreign policy nature may be properly cognizable by the courts". ${ }^{132}$ This is a clear indication that the Supreme Court of Canada rejected the political question doctrine and, by implication, the doctrine of non-justiciability. ${ }^{133}$ It manifests a framework for judicial review based on the merits criteria that reflects the courts approach that they will not refuse jurisdiction because a matter involves foreign states.

\section{Liability of Foreign Countries for Terrorist ConduCt}

The Canadian legislature enacted the Justice for Victims of Terrorist Act (JVTA) 2012 allowing victims of terrorism to sue the perpetrators and supporters of terrorism. These may include supporters of foreign states, provided that the Canadian government has formally listed the state as a supporter of terrorism. This provision in the JVTA sets out that if the if the judgment is against a foreign state, that state

\footnotetext{
Operation Dismantle Inc. v. R. [1985] 1 SCR 441, 467.

Id. at 472.

Id. at 491 .

Id. at 486.

Id. at 453 .

Id. at 443.

Operation Dismantle Inc. v. R. [1985] 1 SCR 441, 459.

33 For further reference, see Re Canada Assistance Plan [1991] 2 SCR 525. According to Sopinka J, '[t] hat there is a political element embodied in the question [before the Court] ... may well be the case. But that does not end the matter' (545). See also Vancouver Island Peace Society v. Canada, [1994] 1 FC 102.
} 
must be on the list referred to in subsection 6.1(2) of the SIA for the judgment to be recognized. . This has been in accordance with the 1996 amendment to the FSIA in the United States that enables victims to sue if the country has been declared as a sponsor of terrorism under S 1605A. ${ }^{134}$

The enactment of the JVTA in Canada led to expatriate Arab communities, who had been victims of violence, bringing group claims against perpetrators allegedly backed by Iran. The litigation commenced once the families of the victims, who had been previously awarded damages against Iran by various U.S. courts, tried to satisfy the U.S. damages awards by seizing Iranian assets in the U.S.

While the various claimants brought separate actions in Canada seeking to enforce their U.S. judgments and recover against Iran's non-diplomatic assets in Canada, the actions were ultimately heard together as a group claim. In Tracy v. Iranian Ministry of Information and Security (2016), the Ontario Superior Court of Justice had to consider the legislative reforms and how they applied to a series of American judgments rendered against Iran in favor of American victims of terrorist acts which Iran was found to have sponsored. The court held that Iran was not immune from the enforcement proceedings and that accordingly the American judgments were enforceable against certain assets of Iran in Ontario. ${ }^{135}$

The plaintiff brought the action under Part 2 of the Criminal Code and section 4 of the Justice for Victims of Terrorism Act. The Court considered issues relating to the limitation period and the enforcement of punitive damages awards (in this case, in the hundreds of millions of dollars). The government of Iran's defense was that the loss or damage suffered by the victim had to have been, in the language of s 4(1) of the JVTA, suffered after January 1, 1985, but the Court held that this didnot prevent the enforcement of American decisions in respect of acts of terror which happened before that date because the victims continued to suffer harm on an ongoing basis. The court's ruling was that damages that were punitive awards were not contrary to public policy. ${ }^{136}$

However, in any appeal, Iran does have a significant procedural problem as it did not defend the actions initially brought in Ontario. The immunity arguments were received by the court as part of Iran's motion to have the resulting default judgments set aside, and not on the issue of whether Iran might have a sustainable defense on the merits. The case concerned the non-diplomatic assets that were available for recovery in accordance with the Vienna Convention on Diplomatic Relations ${ }^{137}$ which were valued at an estimated \$7-8 million and included certain non-diplomatic properties and the contents of various bank accounts.

The Court ordered that Iran's non-diplomatic assets be handed over to the claimants, effectively holding Iran financially responsible for the actions of terrorist

134 Section 1605A states that a foreign state shall not be immune from suits seeking money damages for personal injury or death caused by certain acts like torture and extrajudicial killing - or material support for such acts-by foreign government officials. This provision is limited to countries designated by the United States as state sponsors of terrorism (currently Iran, Sudan, and Syria). It also requires both conduct and injury inside the United States-specifically, "an act of terrorism in the United States" and injury or death "occurring in the United States.

135 Tracy v. Iranian Ministry of Information and Security, 2016 ONSC 3759 (2016).

136 Id. at 109 (2016).

137500 U.N.T.S. 95, entered into force Apr. 24, 1964. 
groups it had allegedly sponsored. The Tracy verdict marks a landmark decision for the victims of terrorist actions who have claimed against the commercial assets of a government that is on the terror list, as was Iran in the Canadian case. The ruling also confirms that the JVTA imposes liability for state-sponsored terrorism in accordance with the Canadian approach to commercial actions seeking compensation for foreign state misconduct. The State Immunity Act provides an escape clause from the immunity of foreign states when it comes to commercial activity. ${ }^{138}$

In commenting on the JVTA and the FSIA section 1605A, Francis Larocque states that "the Canadian model is just as problematic as both statutes ultimately grant or deny immunity by executive fiat, and not through principled assessment of the impugned state act's legal character as continuously required under the restrictive doctrine." ${ }^{139}$ Canada and the United States, in denying foreign sovereign immunity when they have designated a particular country as a state sponsor of terrorism, have eroded state immunity even if they have not established a norm of customary international law because, as the ICJ noted in Jurisdictional Immunities, while the territorial tort exception had "originated in cases concerning road traffic accidents and other "insurable risks" "national legislation codifying the exception was written in more general terms. ${ }^{140}$

\section{CONCLUSION}

The common law doctrine of the Act of State with no foundation in the law of nations has spread and become a universal doctrine with acceptance across states even within the civil law jurisdictions. It has brought about inconsistent results when it has been tested in the courts which have led to critics treating the doctrine with a considerable amount of circumspection. This has not led to its dissipation but has enhanced its use by the adoption of different rules of application by the common law courts, notably in the United Kingdom, the United States, Canada and Australia. The rulings of the courts apply within their jurisdictions but there are principles to be drawn, such as non-justiciability and the political question doctrine, that the courts need to explain when distinguishing their refusal to step into the domain of the executive and drawing a narrow basis for their intervention.

The doctrine is closely linked to the constitutional arrangements in which the issues that come before the courts are decided and the judges have to evaluate their application. It is no surprise that the reluctance of the judiciary to adjudicate upon the issues is premised on the abstract principles of state sovereignty, the separation of powers and the comity of nations. This is the reason why the judiciary has traditionally abstained from adjudicating upon issues which may impact upon the relations between states considering that to be the responsibility of the executive

138 "A foreign state is not immune from the jurisdiction of a court in any proceedings that relate to any commercial activity of the foreign state."

139 Francois Larocque, Torture, Jurisdiction and Immunity, in AleXander Orakhalashvili (ed.), Research Handbook on Jurisdiction and Immunities in International Law 461 (2015).

140 Jurisdictional Immunities of the State (Germany v. Italy: Greece intervening), Judgment, I.C.J. Rep. 99, \ 64 (2012). 
branch of the government. In the common law countries, the judicial interpretation of these concepts comes up against the complex factual and legal questions of a transnational nature which leads to lack of uniformity in the decisions by judges.

The understanding of the U.S. courts has moved from the time when it was determined in Underhill that an act of state doctrine was one of non-decision into a source of principles by which to decide cases on their merits. The decision of the Supreme Court in Sabbatino was to the effect that Act of State is not a requirement of international law, nor is it derived from the Constitution but is a doctrine of federal common law, binding on state as well as federal courts. ${ }^{141}$ The Court ruled that the doctrine rested on the jurisdictional immunities of states and their officials under international law, and not on principles governing the legal effect of foreign official acts in the domestic jurisdiction. ${ }^{142}$

In the Jurisdictional Immunities (Germany v. Italy) case, the principle was established that the jurisdictional immunity is not absolute..." and that "...in cases of crimes under international law, the jurisdictional immunity of States should be set aside." 143 The ICJ's judgment established that State immunity derives from the principle of sovereign equality found in Article 2(1) of the UN Charter and is "one of the fundamental pillars of the international legal order." As between Italy and Germany, this right was derived from customary international law in the absence of a treaty to that effect. Based on its analysis of State practice and opinio juris, the ICJ held that, "...practice shows that, whether in claiming immunity for themselves or according it to others, States generally proceed on the basis that there is a right to immunity under international law, together with a corresponding obligation on the part of other States to respect and give effect to that immunity". ${ }^{144}$

The Court also defined the relationship between jurisdictional immunity and the territorial sovereignty of the forum State by stating that:

This principle [of State immunity] has to be viewed together with the principle that each State possesses sovereignty over its own territory and that there flows from that sovereignty the jurisdiction of the State over events and persons within that territory. Exceptions to the immunity of the State represent a departure from the principle of sovereign equality. Immunity may [also] represent a departure from the principle of territorial sovereignty and the jurisdiction which flows from it. ${ }^{145}$

The Court made its decision on the basis of the European Convention for the Peaceful Settlement of Disputes 1961. Article 27(a) of the Convention states that the Convention did not apply to "disputes relating to facts or situations prior to the entry into force of this Convention as between the parties to the dispute". The Court held that the subject matter of the dispute - the crimes for which reparations are sought occurred during between 1943 and 1945. However, the "...facts or situations" which have given rise to the (present) dispute before the Court are constituted by

141 Banco Nacional de Cuba v. Sabbatino, 376 U.S. 398, 424-27 (1964).

142 Id.

143 Id. (ף \ $27-29)$.

144 Jurisdictional Immunities of the State (Germany v. Italy: Greece intervening), Judgment, I.C.J. Rep. 99, at 9 甲 55 - 56 (2012).

145 Id. at 57. 
Italian judicial decisions that denied Germany the jurisdictional immunity... and by measures of constraint applied to property belonging to Germany." ${ }^{146}$ This occurred between 2004 and 2011. Italy violated its obligation to respect Germany's immunity under international law by allowing civil claims to be brought against Germany based on violations of international humanitarian law between 1943 and 1945, by declaring enforceable in Italy decisions of Greek courts and by taking measures of constraint against German property in Italy. The Court requested Italy to enact legislation, or resort to other methods of its choosing, to ensure that the decisions of its courts and those of other judicial authorities infringing the immunity which Germany enjoys under international law cease to have effect.

It has to be noted that the jurisdictional immunities of states and their officials are governed by international law. The United Nations Convention on Jurisdictional Immunities of States and Their Property was adopted on Dec. 2, 2004 and was opened for signature on 17 January 2005, and is at present short of ratification by 9 states to be effective. ${ }^{147}$ The Preamble states "Judicial immunities of States and their property are generally accepted as a principle of customary international law". The Convention formulates the recognized norms of state practice into rules of conduct for which a State could be liable under international law if the case were to come before the ICJ. Article 5 state: "A State enjoys immunity, in respect of itself and its property, from the jurisdiction of the courts of another State subject to the provisions of the present Convention".

The Convention articulates a restrictive theory of sovereign immunity, rather than the historic absolute immunity. The rules relate to legal proceedings in the courts of another state, do not cover criminal proceedings, and do not allow civil actions in tort liability for human rights abuses against state agents where the abuse has occurred in another country. Liability is not predicated upon serious breaches of jus cogens norms. In that sense it has given precedence to state immunity and reaffirmed the judgment in the Jurisprudential Immunities of the State case. The reasoning seems to be that civil actions for a state agent's misconduct should be brought in the courts of that state and not in a foreign court and the belief that civil litigation by individuals is self-serving. It may have an impact on the relations between both the states.

The United States has not ratified the prospective Convention and it seems that the federal government is reliant on its own domestic legal framework to interpret the doctrine of Act of State. It is by reference to the FSIA and the exceptions that the courts are allowed to intervene and to the CRA and ATCA which can be invoked when the issue of liability arises for injury caused by officials in other jurisdictions. The courts have to be impartial in adjudication and despite the exceptions to the political question doctrine need to be familiar with the grounds for litigation in the courts that may challenge state immunity.

146 Id at 49.

147 U.N. Doc. A/59/508 (not yet in force). 